The Philosophical Journal of Conflict and Violence

Vol. III, Issue $1 / 2019$

(C) The Authors 2019

Available online at http://trivent-publishing.eu/

\title{
Slow Violence and the Limits of Eco-Resistance
}

\author{
Howard Caygill \\ Department of Humanities, Kingston University, \\ United Kingdom, h.caygill@kingston.ac.uk
}

\begin{abstract}
The essay departs from Rob Nixon's concept of slow violence to consider the strategic repertoire of eco-resistance. The fundamental question that it addresses is how far the paradigm of resistance is appropriate for understanding and imaging the practice of radical environmentalism. Along the way it confronts the thanatopolitical assumptions of theories of resistance, asking whether the forms of reactive violence proper to resistance are appropriate for environmental action, but nevertheless attempts to detect an affirmative moment in the non-state future-oriented action. The essay concludes by asking whether the theory and practice of bioregional and other expressions of grass roots environmentalism point to an enhancement of the theory of resistance or to new forms of oppositional environmental action.
\end{abstract}

Keywords: Capacity to Resist; Extinction Rebellion; Ecological struggle; Resistance; Sixth Mass Extinction Event; Slow Violence; Social Movements; Uprising.

DOI: $10.22618 /$ TP.PJCV.20193.1.192001

The PJCV Journal is published by Trivent Publishing

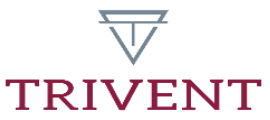

This is an Open Access article distributed in accordance with the Creative Commons Attribution Non Commercial (CC-BY-NC-ND 4.0) license, which permits others to copy or share the article, provided original work is properly cited and that this is not done for commercial purposes. Users may not remix, transform, or build upon the material and may not distribute the modified material (http:/ / creativecommons.org/ licenses/by-nc/4.0/) 


\title{
Slow Violence and the Limits of Eco-Resistance
}

\author{
Howard Caygill \\ Department of Humanities, Kingston University, \\ United Kingdom, h.caygill@kingston.ac.uk
}

\begin{abstract}
The essay departs from Rob Nixon's concept of slow violence to consider the strategic repertoire of eco-resistance. The fundamental question that it addresses is how far the paradigm of resistance is appropriate for understanding and imaging the practice of radical environmentalism. Along the way it confronts the thanatopolitical assumptions of theories of resistance, asking whether the forms of reactive violence proper to resistance are appropriate for environmental action, but nevertheless attempts to detect an affirmative moment in the non-state future-oriented action. The essay concludes by asking whether the theory and practice of bioregional and other expressions of grass roots environmentalism point to an enhancement of the theory of resistance or to new forms of oppositional environmental action.
\end{abstract}

Keywords: Capacity to Resist; Extinction Rebellion; Ecological struggle; Resistance; Sixth Mass Extinction Event; Slow Violence; Social Movements; Uprising.

\section{Introduction}

The attitude towards resistance in the recent radicalisations of ecological struggle is strikingly ambiguous. One of the early organizers of Extinction Rebellion - Gail Bradbrook - reported that the emergent movement almost divided on the name for the movement, eventually opting it seems for Extinction Rebellion instead of Extinction Resistance or other possibilities. ${ }^{1}$ And yet she agreed fully with Tukano indigenous nation activist Daiara Tukano's description of "existence as resistance," 2 a view wholly consistent with the theory and practice of total resistance to what Rob Nixon described as "slow violence" in his now classic reflection Slow Violence and the Environmentalism of the Poor. ${ }^{3}$ Another organizer, Roger Hallam describes the careful and deliberate organization of the Extinction Rebellion in terms of a "civil resistance model" and links the Rebellion to techniques of non-violent resistance pioneered in the Indian Independence Movement and the Civil Rights movement in the USA. And yet, in the movement's "Declaration of Rebellion" resistance itself is not named, appearing instead as "rebellion," "revolt" and "rising." Is this reticence in using the term "resistance" as a motivating term in the open struggle merely verbal, or has the discourse of resistance reached its limit when mobilizing in the face of the grave but not wholly conspicuous threat of incrementally catastrophic climate change?

\footnotetext{
${ }^{1}$ Kate Willis, "Rebels with a Cause," Evening Standard Magazine (May 2019), 14.

2 Gail Bradbrook, "What is Your Place in these Times?," in This is not a Drill: An Extinction Rebellion Handbook (London: Penguin Books, 2019), 185.

3 Rob Nixon. Slow Violence and the Environmentalism of the Poor (Cambridge Mass.: Harvard University Press, 2011).
} 


\section{Resistance and the Uprising}

One of the main theoretical and organizational sources of the Extinction Rebellion strategy - the Engler brothers' This is an Uprising - suggests that the problem with the use of term resistance is more fundamental. This reflection on the lessons of United States activists movements since the Civil Rights movement in early 1960s and the theoretical work of Gene Sharp, Saul Alinsky and Frances Fox Piven departs from the premise that resistance movements have always involved something more than the reactive stance associated with the term "resistance." From the outset, the Englers' discussion of the strategies employed in the Civil Rights campaign of 1963 in Birmingham Alabama insists that it involved more than "high stakes acts of resistance" 5 or no-saying however audacious and inspiring these may have been. And yet in spite of the Engler's references to "eruptions of mass resistance" such as "in Mexico, Turkey, Brazil and Hong Kong" $"$ as well as \#BlackLivesMatter it seems as if resistance is a necessary if not sufficient precondition for contemporary activist strategies. The virtue of the Engler brothers' book however is to point beyond an impasse in the theory of resistance that sees acts of resistance as fugitive reactions to momentarily intolerable conditions. From this point of view resistance seems to be reactive and transitive; it is always resistance to an intolerable state of affairs comprising sometimes extremely courageous acts that seem destined to leave almost intangible traces. And when this state of affairs in considered to be "an event unprecedented in [human] history, one which, unless immediately addressed, will catapult us further into the destruction of all we hold dear: this nation, its peoples, our ecosystems and the future of generations to come"7 then it is easy to see how mere negative resistance may seem insufficient when it becomes a question of affirming the future of life itself on this planet.

A text squarely in the tradition of the theory of resistance such as my On Resistance: $A$ Philosophy of Defiance ${ }^{8}$ attempted to escape this theoretical and strategic impasse through a number of formal operations, most notably the postulation of a Clausewitzian "capacity to resist" that is prior to concrete acts of resistance and associated with an appeal to the paradoxical possibility of an "affirmative resistance." The object of war in Clausewitz's formulation is not so much the resistance of the adversary as their "capacity to resist." Resistance as the enhancement of this capacity ceases to be a reaction to a given state of affairs and becomes a positive end or strategic object in itself. It is possible to affirm the enhancement of the capacity to resist in a number of ways that are not tied to the immediate tactical demands of a given struggle. The capacity to resist is not tied to the present moment of struggle but can also be a legacy from the past and to the future; affirming the capacity permits a more powerful, enduring and successful campaign of resistance.

The Englers' reflections on a number of historically specific practices of resistance - the Civil Rights movement in the USA, the Serbian Optor "resistance" movement, LGBT mobilizations and Occupy Wall Street - seem nevertheless to point beyond even a view of resistance that focuses on the capacity rather than acts of resistance. While paying homage to resistance and some of the logics associated with it, they also discover a number of strategic innovations that enhance its affirmative character and make it appropriate for an action such

\footnotetext{
${ }^{4}$ Mark Engler \& Paul Engler, This is an Uprising: How Nonviolent Revolt is Shaping the Twenty-First Century (New York: Nation Books, 2016).

${ }^{5}$ Ibid., xii.

${ }^{6}$ Ibid., xxi

7 Extinction Rebellion, "Declaration of Rebellion," in This is not a Drill: An Extinction Rebellion Handbook (London: Penguin Books, 2019), 1.

${ }^{8}$ Howard Caygill, On Resistance: A Philosophy of Defiance (London: Bloomsbury Academic, 2013).
} 
as Extinction Rebellion. Not only did the Serbian activists appeal to the precedent of historical "resistance" during the Second World War but they also made a number of strategic innovations in the conduct of resistance struggles that the Englers themselves describe in terms of an emergence of a "civil resistance" that exceeds the received models of resistance strategy. Yet while the practice is still described as "resistance," the term itself and its historical resonances are increasingly sidelined: resistance can no longer be carried out in the name of resistance, but better under such titles as "revolt," "rebellion" and "uprising."

The Engler brothers, building on the work of American theorists Gene Sharp", Saul Alinsky ${ }^{10}$ and Frances Fox Piven, ${ }^{11}$ point to a number of ways in which the new activist strategic posture seems to exceed the limits of the theory of resistance. The first concerns nonviolence. The theory of resistance does not automatically endorse nonviolence; its most influential modern statement by Clausewitz is indeed framed by the context of violent warfare. While it was innovatively developed by Ghandi and his successors in the direction of a nonviolent strategy in an acknowledged state of war, resistance as a tactic is theoretically indifferent to the use of violent or nonviolent means. The classic way of justifying nonviolent resistance - adopted by Ghandi in his notion of the character of the satyagrahist - was to appeal to its ethical character as an act of exemplary and unusual moral sacrifice. This position was fundamentally contested by Gene Sharp, whose argument for nonviolence rested less on the grounds of moral value than on those of strategic efficacy - that nonviolent resistance is an efficient and effective strategy for entering into and winning an asymmetrical conflict. This position is adopted by the Engler brothers and is central to their accepting and developing Sharp's term "civil resistance" as their primary strategic axiom.

With respect to nonviolence, the qualified use of the expression "nonviolent resistance" as an effective strategic position is certainly justifiable. This is also the case with a second and corollary position held by the Englers, which is that resistance is not just a spontaneous outburst of revolt or defiance. The classic Leninist objection to resistance deriving from What is to be Done holds that it is largely a spontaneous reaction to insupportable circumstances that flares up and rapidly disappears back into the darkness of subaltern history. The Engler brothers argue against this that resistance can, indeed must be carefully planned and organized, drawing on resources from the past and aiming for sustained action in the future. Their reinvention of Clausewitz's "capacity to resist" is presented in terms of a mediating position between the primacy of community organization associated with Alinsky and his followers, and the affirmation of spontaneity by Piven; they claim that

[t]he future of social change in this country may well involve integrating these approaches...The emerging field of civil resistance offers considerable potential in addressing this task, providing tools that can help create a synthesis between competing traditions. ${ }^{12}$

Their readings of the cultures of resistance informing and supporting the initiatives of the Civil Rights movement and the resistance movements they study is consistent with the Clausewitzian attention to the capacity or ability to resist (Widerstandsfähigkeit), or in their terms the "skills" of resistance rather than apparently spontaneous acts of resistance. The Engler brothers point to the central role played by organization in apparently spontaneous

\footnotetext{
${ }^{9}$ Gene Sharp, The Politics of Nonviolent Action, 3 vols., (Boston: Porter Sargent Publishers, 1973).

${ }^{10}$ Saul Alinsky, Rules for Radicals: A Pragmatic Primer for Realistic Radicals (New York: Vintage Books, 1989).

${ }^{11}$ Frances Fox Piven \& Richard A. Cloward, Poor People's Movements: Why They Succeed, How They Fail (New York: Vintage Books, 1979).

12 Ibid., 32
} 
acts of resistance, and they describe the kinds of organizational structure they deem appropriate not only to mounting but also sustaining resistance. This is certainly confirmed by the carefully planned and executed actions of Extinction Rebellion that succeeded in creating organizational forms that guided their actions, especially their strategic withdrawals, without stifling the joy or initiative of struggle.

While the issues of violence and organization may be contained without compromising the limits of the theory of resistance, the final strategic posture described by the Engler brothers and adopted by Extinction Rebellion does pose a considerable challenge. It concerns the paradox of an affirmative resistance, a resistance that does not react to circumstances but seizes the initiative in shaping them. Clausewitz experienced considerable difficulty in understanding how resistance - by definition reactive and even defensive - could seize the initiative. For him, a condition for success in a conflict consisted in seizing the initiative and defining the character of the battlefield and the terms of engagement. From this perspective resistance, and even the "capacity to resist," however positively construed, seems always to be already on the defensive and at a disadvantage with respect to its adversary.

\section{The Uses of Escalation}

The response of the Engler brothers is to adopt a term and a practice that was a matter of considerable disquiet to Clausewitz himself - escalation. In their fascinating description of the emergence of strategic positions in the Civil Rights struggle for Birmingham, Alabama in 1963 they describe Dr King's decision to risk jail as a strategic gamble through which "he could both move others to step forward and reassert a sense of escalating drama in the Birmingham drive."13 The reference to "escalation" here is not casual and it recurs throughout the text, even if it is not acknowledged in the admirably full index. Their critique of spontaneous eruptions of defiance is framed in terms of their inability "to escalate or to sustain multiple waves of protest over a period of years." ${ }^{14}$ Dr King's "Project C" (C for "confrontation") is an example of a strategy of escalation, which, as the Engler brothers concede, provoked strong criticisms from understandably risk-adverse local organizers and activists. ${ }^{15}$ However, for the Engler brothers controlled escalation is the means by which a resistance movement is able to seize the initiative, determine the nature of the battlefield and set the terms of its present and future engagements.

For the Engler brothers controlled escalation is the way to overcome the limits of mere resistance and the problems it raises: "For as long as people have experimented with building movements around strategic nonviolence, they have grappled with a dilemma: how to reconcile the explosive short-term potential of disruptive power with the need to sustain resistance to meet long-term goals." 16 Escalation in other words is the missing term in equating the factors of spontaneity, initiative and a sustainable, organizational capacity to resist. Both the Civil Rights and the Serbian Optor movements provide models for how "dissidents employing militant nonviolent tactics could gradually increase pressure over time, escalating through multiple stages of uprising that were spread over years." 17 Controlled, phased and strategically planned escalations of resistance could support and enhance both the organization and the constituency of "civil resistance" by making it strategically effective in Clausewitzian terms and able to seize the initiative and choose the time and place of struggle. In this way it is the adversary who is forced into a reactive, "resistant" position with respect to the initiative of

\footnotetext{
13 Ibid., 20.

14 Ibid., 28.

15 See Ibid., 48.

16 Ibid 62.

17 Ibid.,63.
} 
the resisters. The Engler brothers describe this strategy as "Momentum building" and see it as a movement of intensification that combines action and organization destined to arrive at the "moment of the whirlwind" that "is the endpoint of escalation."18 The "weapon of resistance," as Subcommandante Marcos once ironically described it, is revealed to be the capacity to escalate in a cumulative and controlled manner.

The resort to escalation as a strategy marks the point where the theory and practice of momentum building exceeds or transforms the theory of resistance. Clausewitz believed that escalation has to be employed with great circumspection and foresight, for it is intrinsically unpredictable, depending on being able to predict and match the will and the capacity of the adversary to escalate in response. He considered it the resort of gamblers and risk takers, since it would initiate movements that would escape the control of both adversaries. It is the resort of those strategists who have nothing to lose on a final throw of the dice, such as Napoleon towards the end of his military career. It is not something that Clausewitz would associate with the dogged and persistent work of resistance. And yet in the case of civil resistance it does make sense in specific circumstances. One is the scenario of "slow violence" described by Rob Nixon, where the war remains inconspicuous unless it is escalated and driven into visibility; while another is the predicament where the alternative to escalation is mutual assured destruction. The recent mobilizations of Eco-Resistance such as Extinction Rebellion consider both circumstances to be operative: the enemies in the "climate war" remain inconspicuous and hidden until the struggle against them is escalated, and the failure to escalate in the circumstances of what is believed to be the Sixth (Human) Mass Extinction Event is assured destruction of human life on this planet.

Rob Nixon's analyses of "slow violence" contrast the rapid, visible violence of open warfare with the slow and inconspicuous violence of daily, routine attrition. Visible violence is fully compatible with slow violence, as in Nixon's analysis of the use Agent Orange in Vietnam that was both an act of extreme visible violence with slow and drawn out invisible consequences in illness and suffering that last decades. Indeed, Nixon argues, the fast, spectacular violence of war and catastrophe takes place against an almost invisible backdrop of slow, inconspicuous violence:

By slow violence I mean a violence that occurs gradually and out of sight, a violence of delayed destruction that is dispersed across time and space, an attritional violence that is typically not viewed as violence at all. Violence is customarily conceived as an event or action that is immediate in time, explosive and spectacular in space, and as erupting into instant sensational visibility. ${ }^{19}$

In this respect, the controlled escalation of "civil resistance" is dedicated to exposing the work of slow violence by accelerating it. The Engler brothers describe the campaign in Birmingham and by extension the entire Civil Rights movement as an attempt to expose the slow violence of routine and thoughtless racism. Dr. King's actions were aimed not to engage in uncontrolled escalation but to accelerate conflict sufficiently "to expose the violence routinely inflicted upon the black community under Jim Crow segregation." "We merely bring to the surface the hidden tension that is already alive," King wrote. "We bring it out in the open where it can be seen and dealt with." 20 This distinguished the escalation of the resistance in

\footnotetext{
18 Ibid., 189.

${ }^{19}$ Rob Nixon, Slow Violence and the Environmentalism of the Poor (Cambridge Mass.: Harvard University Press, 2011), 2.

${ }^{20}$ Mark Engler \& Paul Engler, This is an Uprising: How Nonviolent Revolt is Shaping the Twenty-First Century, 22.
} 
Birmingham, Alabama from the routine daily resistance of the community there; this escalation was driven by the conviction that the truth of slow violence could be exposed through controlled and conscious escalation.

The strategy of controlled escalation is appropriate for contexts that Clausewitz described as those of "imperial peace" or the peace of the victors. In these contexts, the ongoing war is no longer conspicuous, and the exercise of violence has de-accelerated to the point of invisibility. The main focus of Rob Nixon's analysis is the environmentalism of the poor, referring to slow violence of ecological destruction. While the effects of climate change are brutally felt, the causes and the beneficiaries of it remain largely inconspicuous, as does the level of threat under which the world's population now lives. For this reason, the approach of escalating civil resistance described by the Englers proved significant for Extinction Rebellion. Theirs was an attempt to make visible the threat of climate change to human life on the planet and to call for immediate radical change. This was not an exercise in resisting the slow violence of climate change on the terms of engagement set by corporations and governments but seizing the initiative by changing the terrain of struggle and building up a sustained momentum of resistance.

\section{Extinction Rebellion and the Joyous Revolt}

Extinction Rebellion followed the strategic council of the Engler brothers' view of "civil resistance" by combining organization with a controlled escalation or threat of escalation of the level of struggle. Extinction Rebellion's UK actions included occupations of Oxford Circus, Marble Arch, Waterloo Bridge, Piccadilly Circus and Parliament Square in London in April 2019 with mass actions directed against fossil fuel companies, the Treasury and the Stock Exchange and a threat of sustained action against Heathrow Airport. Their strategic profile conforms both to the drive to make visible an otherwise inconspicuous slow violence - "Tell the Truth" - and to raise the stakes in a struggle for which its activists are convinced the alternatives are either victory or the end of life on this planet - "This time, we are literally fighting for our lives." 21 For this reason Extinction Rebellion are fully prepared to escalate the struggle while building up organizational momentum. And it is for the same reason that they could not adopt the name of Extinction Resistance, since this would concede the initiative to the forces carrying through the Sixth (Human) Extinction Event. The Rebellion does not just say no to extinction, but more affirmatively it says yes to the lives of future generations.

When describing the strategy of Extinction Rebellion, Roger Hallam cites the "civil resistance model" described by the Engler brothers but describes a suite of actions that in some respects goes beyond the limits of the theory of resistance. The numbers of actors required is several thousand and the choice of battlefield is the capital city in order to gain the attention of the elites and their media. So far this is consistent with Civil Rights precedent, as is the further condition of deliberately breaking the law. The latter is justified in strategic terms of creating the "social tension and public drama that are vital to create change." 22 After choosing the terrain of struggle the next strategic step is to escalate the struggle by deliberately crossing the border of law-abiding demonstration. With this the movement seizes the narrative "It's the great archetypal story in all cultures: against the odds the brave go into battle against evil." It also serves to show the adversary that "you are serious and unafraid" and creates "the necessary material and economic cost" to earn the elite's attention. The actions must

${ }^{21}$ Danny Burns and Cordula Reimann, "Movement Building", in This is an Uprising: How Nonviolent Revolt is Shaping the Twenty-First Century, 108.

22Ibid., 101. 
also be nonviolent and extended over a long period - they must cease to be an event but become a felt crisis. And finally, the actions must be life-affirming and joyful — "We are going to show the media that we are not sitting around patiently waiting to die any longer. We're going to have a party. Obviously." 23 With these strategic recommendations Extinction Rebellion set to work on a project of affirmative resistance, making explicit what is often underemphasized in the resistance movements.

The joy of escalation and saying yes to life marks an intensification of the theory and practice of resistance, releasing it from its often thanatopolitical premises. The appeals to the "already dead" of the resistance or to "revolutionary suicide" as a model for resistant action give way to an affirmation of life. This always accompanied resistance movements but, with perhaps the exception of the Greenham Common Women's Peace Camp, was never explicitly thematized as an essential strategic posture. Resistance as life is in this case explicit and clear, but it is not so clear whether this "civil resistance" of joyful, life affirming escalation can still be categorized as resistance or whether it constitutes a moment or ecstatic point of reference in an extended campaign of ecological resistance. We may conclude that either the forms of resistance currently emerging in the context of ecological struggle mark its radical metamorphosis into a new phase or that the perceived stakes of human and wider species extinction remain too high to be left to resistance alone.

\section{References}

Alinsky, Saul. Rules for Radicals: A Pragmatic Primer for Realistic Radicals. New York: Vintage Books, 1989.

Caygill, Howard. On Resistance: A Pbilosophy of Defiance. London: Bloomsbury Academic, 2013. Engler, Mark \& Engler, Paul. This is an Uprising: How Nonviolence Revolt is Shaping the Twenty-first Century. New York: Nation Books, 2017.

Extinction Rebellion. This is not a Drill: An Extinction Rebellion handbook. London: Penguin Random House, 2019.

Fox Piven, Frances \& Cloward, Richard A.. Poor People's Movements: Why They Succeed, How They Fail. New York: Vintage Books, 1979.

Nixon, Rob. Slow Violence and the Environmentalism of the Poor, Cambridge Mass.: Harvard University Press, 2011.

Sharp, Gene. The Politics of Nonviolent Action, 3 vols. Boston: Porter Sargent Publishers, 1973.

23 Ibid., 102. 